\title{
Ameliorating Effects of Moxifloxacin on Endotoxin-Induced Acute Lung Injury in Rats
}

Young Man Lee ${ }^{1}$ and Whi Gun Chae ${ }^{2}$

${ }^{1}$ Department of Physiology, ${ }^{2}$ Department of Biochemistry, School of Medicine, Daegu Catholic University, Daegu 705-030, Korea

Received July 13, 2011 /Revised July 28, 2011 /Accepted July 29, 2011

\begin{abstract}
The immunomodulating effects of moxifloxacin seem to be effective in downregulating inflammatory reactions. This presumed effect was tested in endotoxin (ETX)-induced acute lung injury (ALI) in rats. After moxifloxacin treatment $(10 \mathrm{mg} / \mathrm{kg})$ of ETX-given rats, lung myeloperoxidase (MPO) activity, bronchoalveolar-lavage (BAL) protein, and the number of neutrophils in the BAL cells were measured. Light and electron microscopic structures were also examined. Electron microscopic $\mathrm{CeCl}_{3}$ histochemistry for the detection of hydrogen peroxide in the lungs and immunohistochemistry of cytosolic phospholipase A2 (cPLA2) in the lung tissues and BAL cells were performed. To examine the expression of TNFa in the lungs, western blotting was carried out with the lung tissues. ETX had accumulated neutrophils in the lungs, which was followed by lung leak. Oxidative stress occurred, and increased expression of CPLA2 in the lung tissues and BAL cells was observed in the ETX-given rats. Simultaneously, the expression of TNFa was enhanced by ETX. Moxifloxacin, however, decreased all these parameters, indicating that ALI may have been ameliorated. Moxifloxacin appears to ameliorate ETX-induced ALI partially through the suppression of cPLA2 in the lungs of rats.
\end{abstract}

Key words : Endotoxin, induced acute lung injury (ALI), cytosolic PLA2, moxifloxacin

\section{Introduction}

The pathophysiology of sepsis-induced acute lung injury (ALI) is characterized by the elevation of the inflammatory lipid mediators, free radicals from phagocytes causing oxidative stress and disruption of the endothelial and epithelial barrier in the lungs [16].

Of these causative factors, to elicit acute inflammatory pulmonary edema, proinflammatory cytokines and products of activated phospholipase A2 (PLA2) play critical roles in septic ALI [21]. In patients with septic ALI, the levels of proinflammatory cytokines and lipid mediators are elevated [24].

The increased levels of cytokines are followed by the activation of PLA2s, which releases several proinflammatory lipid mediators [1]. The chemokines and lipid molecules collectively lead to the chemotaxis of neutrophils into the lungs, and the accumulated neutrophils provoke oxidative stress and proteolytic inflammatory tissue injury [27]. The accumulation of neutrophils in the lungs is initiated by chemokines such as cytokine-induced neutrophil chemoattractant (CINC), but more importantly, as an

\footnotetext{
*Corresponding author

Tel : +82-53-650-4472, Fax : +82-53-621-4106

E-mail : leeym@cu.ac.kr
}

effector of proinflammatory cytokines, PLA2s regulate the rate of inflammation by releasing proinflammatory lipid mediators [12].

The pathophysiology of sepsis-induced ALI, however, is not that simple. Endotoxin (ETX) itself induces the immune system to process monocytes and macrophages to secrete various cytokines, and to activate transcriptional factor $\mathrm{NFkB}$ to initiate heterogeneous inflammatory reactions such as activation of adhesion molecules, coagulation process, and release of proteolytic enzymes from the neutrophils [18]. The activation of PLA2s is only one of the processes for eliciting an inflammatory reaction in the lungs during ALI.

Recent studies on PLA2s, however, revealed new concepts on the roles of PLA2 associated with inflammation because successively novel PLA2s have been found, and these newly found PLA2s (including subtypes of CPLA2s) are presumed to have certain roles in the pathogenesis of inflammatory reaction [10].

As one of the PLA2s that seem to be responsible for the inflammation in septic ALI, cytosolic PLA2 (cPLA2) is known to be involved in the neutrophilic oxidative stress and inflammation in the lungs [13].

As the migration and release of proteolytic enzymes of neutrophils are regulated by the CPLA2-derived lipids, their suppression or inhibition could be beneficial in terms of 
diminishing lung tissue injury. Unfortunately, however, the trials that have been conducted to develop a new modality for treating ALI with the suppression of PLA2s have failed.

Moxifloxacin was recently elucidated to have immunoregulating effects, including suppression of neutrophilic migration and generation of proinflammatory cytokine from monocytes [3]. The anti-inflammatory effects of moxifloxacine, especially on LPS-induced ALI, were suggested in certain literature [8].

In conjunction with the anti-inflammatory effects of moxifloxacin and the role of PLA2 in ALI, the possibility of the ameliorating property of moxifloxacin on ETX-induced ALI was probed in association with CPLA2 activation and neutrophilic oxidative stress.

\section{Materials and Methods}

\section{Reagents and experimental animals}

Endotoxin ( $E$ coli type 0127 ; B8) was purchased from Sigma Aldrich Chemical Company (St. Louise, MO, USA). Goat anti-human cPLA2 polyclonal antibody was purchased from Santa Cruz Biochem (Santa Cruz, CA, USA). Anti-TNF a-polyclonal antibody was obtained from Cell Signaling (Danvers, MA, USA). Moxifloxacin hydrochloride was graciously provided by Bayer (Leverkusen, Germany). All other reagents were purchased from Sigma Aldrich Chemical Company (St. Louise, MO, USA). Sprague-Dawley rats (male 250-300 g) were purchased from Sasco Korea and was fed ad libitum standard chow and water till experiments

\section{Experimental groups}

Rats were allotted to three experimental groups

1) Sham group; rats were given $1.0 \mathrm{ml}$ of normal saline intratracheally.

2) ETX group; rats were given $100 \mu \mathrm{g}$ of ETX in $1.0 \mathrm{ml}$ of normal saline intratracheally.

3) ETX+MO group; rats were given $100 \mu \mathrm{g}$ of ETX in 1.0 $\mathrm{ml}$ of normal saline intratracheally and immediately after the instillation of ETX, moxifloxacin hydrochloride $(\mathrm{MO}, 10 \mathrm{mg} / \mathrm{kg}$ ) was given intraperitoneally.

\section{Induction of ALI}

Rats were anesthetized with enflurane and xylazine and trachea was exposed. Eighteen gauge angiocatheter was inserted into the trachea and $100 \mu \mathrm{g}$ of ETX in $1.0 \mathrm{ml}$ of saline was insufflated. Five hours later, the rats were sacrificed for experiments.

\section{Lung preparations for morphological examination}

1) Light microscopic preparations; Lungs were fixed by inflation with paraform aldehyde (4\%, $\mathrm{pH} 7.4)$ under the pressure of $20 \mathrm{~cm} \mathrm{H}_{2} \mathrm{O}$ and were sliced before immersing into paraform aldehyde, then degassed and fixed. Lung slices were stained with hematoxylin and eosin (H\&E) for examining lung morphology. The slides were examined with AxioPhot photomicroscope (Carl Zeiss, Oberkochen, Germany) and were taken photos with AxioCam MRc5 (Carl Zeiss, Oberkochen, Germany)

2) Electron microscopic preparation for morphology and detection of hydrogen peroxide; Five hours after ETX insufflation, rats were anesthetized with enflurane and xylazine, thoracotomy was performed. Lungs were removed and small blocks of tissue (approximately 1 $\left.\mathrm{mm}^{3}\right)$ were fixed in cold glutaraldehyde solution $(4 \%$, 4 hours, $2.5 \%$ glutaraldehyde in $0.1 \mathrm{M} \mathrm{PBS}, \mathrm{pH} 7.4$ ). Air was removed from the tissue by capping the sample vial and pressurized $\left(20 \mathrm{~cm} \mathrm{H}_{2} \mathrm{O}\right)$. After fixation, samples were rinsed before postfixation with $1 \% \mathrm{OsO}_{4}$ in $0.1 \mathrm{M}$ PBS for 2 hours at room temperature. Then the samples were dehydrated with graded ethanol and propylene oxide and embedded in epoxy resin. Block sections were subject to ultramicrotomed (Sorvall MT-7000), stained with uranyl acetate and lead citrate, then examined using transmission electromicroscope (TEM, Hitachi H-600) at $75 \mathrm{kV}$.

For localization of hydrogen peroxide, the fresh lung tissues were reacted with cerium chloride by which hydrogen peroxide in the lung tissues reacts to form electron dense cerrous perhydroxide deposits [26]. Briefly, after air was removed from tissues, samples were incubated for $1 \mathrm{hr}$ at $37^{\circ} \mathrm{C}$ in $0.1 \mathrm{M}$ Tris-maleate buffer ( $\left.\mathrm{pH} 7.5\right)$ with $7 \%$ sucrose, $10 \mathrm{mM}$ 3-amino-1,2,4-triazol, $2 \mathrm{mM} \mathrm{CeCl} 3$ and $0.0002 \%$ TritonX-100. Then the samples were successively rinsed in $0.1 \mathrm{M}$ Tris maleate buffer $(\mathrm{pH} 7.5)$ with $7 \%$ sucrose and then $0.15 \mathrm{M}$ sodium cacodylate buffer ( $\mathrm{pH} 7.4$ ) for $2 \mathrm{hr}$ at room temperature, dehydrated with graded ethanol and propylene oxide and embedded in epoxy resin. Block sections were ultramicrotomed (Sorvall MT-700), stained with uranyl acetate, then examined using TEM (Hitachi $\mathrm{H}-600)$ at $75 \mathrm{kV}$. To increase the contrast of cerrous perhydroxide, counter stain was not performed. 


\section{Measurement of BAL protein and enumeration of BAL neutrophils:}

Lungs were lavaged by cannulating the trachea and instilling $8.0 \mathrm{ml}$ of saline into the lungs, withdrawing and reinstilling 3 times and then extracting as much fluid as possible. Collected lavage was centrifuged at 1,000× $g$ for $10 \mathrm{~min}$. The cellular pellet was resuspended with $1.0 \mathrm{ml}$ of distilled water and $1.0 \mathrm{ml}$ of Hank's balanced salt solution for a few seconds and centrifuged again. After supernatant was collected for protein measurement, the pellet was resuspended in $0.5 \mathrm{ml}$ of normal saline. With $100 \mu \mathrm{l}$ of resuspended solution, cytospin was performed for a differential count, and the cells were Wright stained. White blood cells were counted with hemocytometer, and the fraction of neutrophils was calculated by percentage of neutrophils in the differential count. With the collected supernatant, BAL protein was measured as previously described by Brown et al [23].

\section{Measurement of lung MPO activity}

Lung myeloperoxidase (MPO) activity was measured as previously described by Goldblum et al [5]. Briefly, the frozen left lung at $-70^{\circ} \mathrm{C}$ was thawed and then homogenized

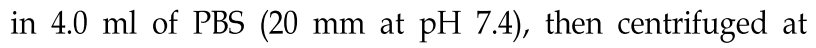
$30,000 \times g$ for $30 \mathrm{~min}$ at $4^{\circ} \mathrm{C}$. The supernatant was discarded, and the pellet was resuspended in $4.0 \mathrm{ml}$ of PBS (50 mM, $\mathrm{pH} 6.0$ ) with $0.5 \%$ hexadecyltrimethylammonium bromide. Lung homogenate was then sonicated for 90 seconds on ice at maximum power, incubated for $2 \mathrm{hr}$ at $60^{\circ} \mathrm{C}$ to inactivate tissue MPO inhibitors and then assayed with o-dianisidine as the substrate.

$$
\text { Immunohistochemistry of CPLA2 in the lung }
$$

tissues and BAL cells

Ultrathin sectioned films of lung tissues were subjected to staining for diaminobenzidine (DAB) for CPLA2, polyclonal antibody (C-20, dilution 1:100, Santa Cruz, CA, USA) was used as first antibody. The antibody complex was visualized by DAB staining. Cytospinned cells were subjected to staining for fluorescence for cPLA2 in BAL cells. Goat anti-human cPLA2 polyclonal antibody (C-20, dilution 1:20, Santa Cruz, CA, USA) was used as first antibody. The antibody complex was visualized by propidium iodide staining.

\section{Protein expression of $\mathrm{TNFa}$}

Protein of TNF $\alpha$ was identified in homogenized lung tissue (100 $\mu \mathrm{g}$ of protein) using standard western blotting. Specific polyclonal antibody, anti-TNF $\alpha$ was diluted in 1:1,000 [tris buffer, saline Tween 20 (TBST) buffer with $0.1 \%$ BSA].

\section{Statistical analyses}

Data were analyzed using one way analysis of variance with Tukey-Kramer multiple comparisons test. A $p$ value of $<0.05$ was considered statistically significant.

\section{Results}

In the sham-treated rats, the lungs showed patent alveoli devoid of phagocytes (Fig. 1a). By contrast, the lungs of the rats in the ETX group showed massive perivascular cuffing, and migration of neutrophils was noted (Fig. 1b, c, d, e, f). The perivascular cuffing was very wide (Fig. 1b, bidirectional arrow), and disruption of the endothelial barrier was noted (Fig. 1b, arrow). In the perivascular cuff, neutrophils were seen migrating into the alveoli (Fig. 1c). In Fig. 1d, at the disrupted endothelial barrier, neutrophils were seen moving towards the alveoli (arrows). The extended vascular cuffing was so wide that the normal architecture of the alveoli was destroyed and alveolar flooding was observed. Neutrophils were visible in the perivascular cuff (Fig. 1e). In Fig. 1f, numerous neutrophils and hyaline membranes were visible in the alveoli (arrow). The site of the disrupted alveolar septa where neutrophils were accumulated was noted (arrow). In Fig. $1 \mathrm{~g}$ and $\mathrm{h}$, the effects of moxifloxacin were disclosed. In the patent alveoli, neutrophils were difficult to find, but interestingly, monocytes were clumped in the alveoli (Fig. 1g, arrows). On the whole, the alveoli were patent, and infiltration or migration of neutrophils into the alveoli was not observed (Fig. 1h).

ETX tremendously increased the accumulation of neutrophils in the lungs compared with the sham group. The lung MPO activity (U/g of the lungs) of the ETX group was higher than that of the sham group $(p<0.001)$. Moxifloxacin decreased the lung MPO activity compared with ETX ( $p<0.05)$. Likewise, the number of BAL neutrophils showed similar results. The number of neutrophils was higher in the ETX group than in the sham group $(p<0.001)$. The number of BAL neutrophils in the ETX group was reduced by moxifloxacin $(p<0.05)$ (Table 1$)$.

As an index of lung injury, the protein content in BAL 

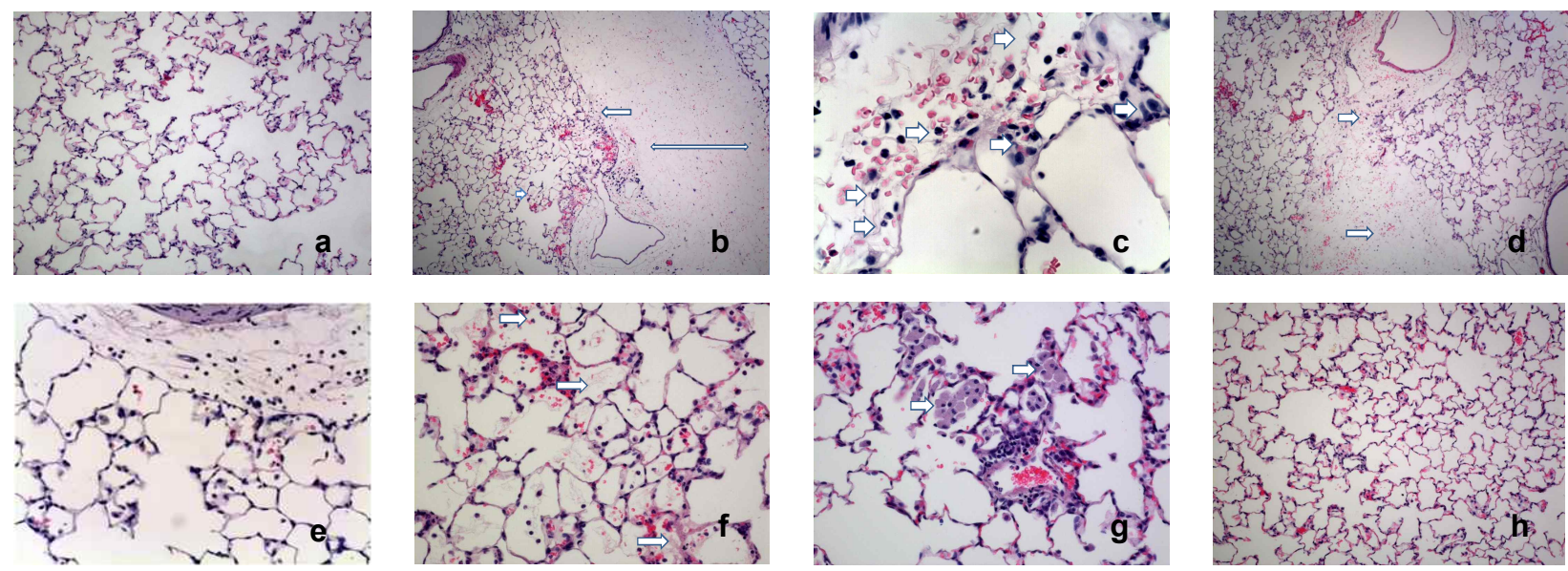

Fig. 1. Effects of moxifloxacin on the lung histology. Fig. 1a: In the sham group, normal patent alveoli and septa were observed. Phagocytes were not observed in the lungs (H\&E staining, original mag $\times 100$ ). Fig. 1b and Fig. 1c: By contrast, in the ETX group, wide perivascular cuffing (Fig. 1b, bidirectional arrow, H\&E staining, original mag $\times 40$ ) and disruptions of the endothelial lining were visible (Fig. 1b, arrow). Through the endothelial disruptions, neutrophils were found migrating into the alveoli, and at the vicinity of the perivascular cuffing red blood cells and phagocytes were accumulated (Fig. 1c, H\&E stain, original mag $\times 400$ ) and hyaline membranes were visible (Fig. 1b, short arrow, H\&E staining, original mag $\times 40$ ). Fig. 1d and Fig. 1e: Through the disrupted endothelial barrier, phagocytes were found moving into the alveoli, and alveolar flooding was found to sweep over the alveoli (Fig. 1d, arrows, H\&E stain, original mag $\times 40$ ). In the alveolar flood, phagocytes were seen floating into the alveoli (Fig. 1e, arrows, H\&E staining, original mag $\times 200$ ). Fig. 1f: Infiltrated neutrophils in the alveoli and hyaline membranes were observed (arrows). Some alveoli were filled with phagocytes and proteinaceous fluid, which led to atelectasis of the lungs (H\&E staining, original mag $\times 200$ ). Fig. 1g: The effects of moxifloxacin reveal the migration and filling of alveoli with monocytes (arrows, H\&E staining, original mag $\times 200$ ). Fig. $1 \mathrm{~h}$ : In the perivascular area, extravasations and dense cuffing of monocytes was observed, but the alveoli were relatively patent, and alveolar flooding was not visible. Generally, alveoli are patent, and neutrophilic migrations and hyaline membranes were difficult to find (H\&E staining, original mag $\times 40$ ).

(mg/two lungs) is presented in Table 2. In the ETX group, the protein content was higher than that of the sham group $(p<0.001)$. By contrast, moxifloxacin decreased $(p<0.05)$ the protein content in the BAL of the ETX group.

Normal lamellar bodies were observed in the cytoplasm of the alveolar type II (AT II) cells. By contrast, enlarged, vacuolated lamellar bodies were observed in the cytoplasms

Table 1. Effects of moxifloxacin on the accumulation and migration of neutrophils in the lungs of rats given endotoxin intratracheally

\begin{tabular}{|c|c|c|c|}
\hline & Sham & ETX & $\mathrm{ETX}+\mathrm{MO}$ \\
\hline $\begin{array}{l}\text { MPO } \\
\text { (U/g of lung) }\end{array}$ & $\begin{array}{c}4.39 \pm 1.28 \\
(n=10)\end{array}$ & $\begin{array}{c}39.6 \pm 11.64^{\mathrm{a}} \\
(\mathrm{n}=10)\end{array}$ & $\begin{array}{c}18.15 \pm 2.62^{b} \\
(n=10)\end{array}$ \\
\hline $\begin{array}{l}\text { BAL neutrophils } \\
\text { (millions/two lungs) }\end{array}$ & $\begin{array}{c}0.09 \pm 0.04 \\
(n=7)\end{array}$ & $\begin{array}{c}4.94 \pm 1.55^{\mathrm{c}} \\
(\mathrm{n}=10)\end{array}$ & $\begin{array}{c}1.57 \pm 2.62^{d} \\
(n=11)\end{array}$ \\
\hline
\end{tabular}

Values are given as mean \pm SE.

$\mathrm{n}$ indicates number of experiments.

a: $p<0.001$, Sham vs ETX, b: $p<0.05$, ETX vs ETX \pm MO.

c: $p<0.001$, Sham vs ETX, d: $p<0.05$, ETX vs ETX \pm MO

ETX: endotoxin, MO: moxifloxacin, BAL: bronchoalveolar lavage of the AT II cells of the rats in the ETX group. Moxifloxacin preserved the lamellar bodies in the cytoplasm of the AT II cells. Even though the lamellar bodies in the MO group were not as intact as those in the sham group, they were relatively well preserved in the former (Fig. 2).

In the sham group, cerrous perhydroxide granules were not found around the AT II cells. By contrast, dense deposits of cerrous perhydroxide were found along the membranes of the AT II cells in the ETX group. Moxifloxacin, however, conspicuously reduced the deposits of cerrous perhydroxide

Table 2. Effect of moxifloxacin on endotoxin-induced lung leak in rats

\begin{tabular}{lccc}
\hline & $\begin{array}{c}\text { Sham } \\
(\mathrm{n}=10)\end{array}$ & $\begin{array}{c}\text { ETX } \\
(\mathrm{n}=10)\end{array}$ & $\begin{array}{c}\text { ETX+MO } \\
(\mathrm{n}=10)\end{array}$ \\
\hline $\begin{array}{l}\text { BAL protein } \\
(\mathrm{mg} / \text { two lungs })\end{array}$ & $2.18 \pm 0.46$ & $5.82 \pm 0.92^{\mathrm{a}}$ & $3.52 \pm 0.77^{\mathrm{b}}$ \\
\hline
\end{tabular}

Values are gives as mean \pm SE.

$\mathrm{n}$ inducates number of experiments.

a: $p<0.001$, Sham vs ETX, b: $p<0.05$, ETX vs ETX \pm MO

ETX: endotoxin, MO: moxifloxacin, BAL: bronchoalveolar lavage 
granules in the ETX-given rats (Fig. 3).

With DAB staining, the expression of CPLA2 was examined. In the sham group, the lungs showed patent alveoli, and few cells with activated cPLA2 were found (Fig. 4a). By contrast, in the ETX group, numerous neutrophils whose cytoplasm was deeply stained with DAB were congested in the vascular lumen (arrow), and some were in the process of diapedesis (Fig. $4 \mathrm{~b}$ ). Again, in the ETX group, the intima of the pulmonary capillary was deeply stained with DAB, which signifies the presence of CPLA2 activated by ETX. Several neutrophils with activated cPLA2s were found (Fig. 4c). Fig. 4d, e, and $\mathrm{f}$ show the effect of moxifloxacin on the activation of CPLA2 in the lungs of the rats in the ETX group. On the whole, the alveoli were patent, and specific pathological findings were not observed. A couple of monocytes were noted (arrow) (Fig. 4d). Although massive extravasation of phagocytes occurred, monocytes were mainly visible, and few DAB-stained cells were found (Fig. 4c). In addition, even though extravasated phagocytes were congested in the interstitium and perivascular space, few DAB-stained cells were found (arrows, Fig. 4f).

Almost all the BAL cells from the sham group were monocytes, which did not show stained cPLA2s. By contrast, the BAL cells from the ETX group showed bright, fluorescent neutrophils with activated cPLA2s. These activated-cPLA2containing neutrophils disappeared almost completely, however, due to moxifloxacin (Fig. 5).

The expression of TNFa was upregulated by ETX, but moxifloxacin suppressed the upregulated expression of TNF a by ETX (Fig. 6).
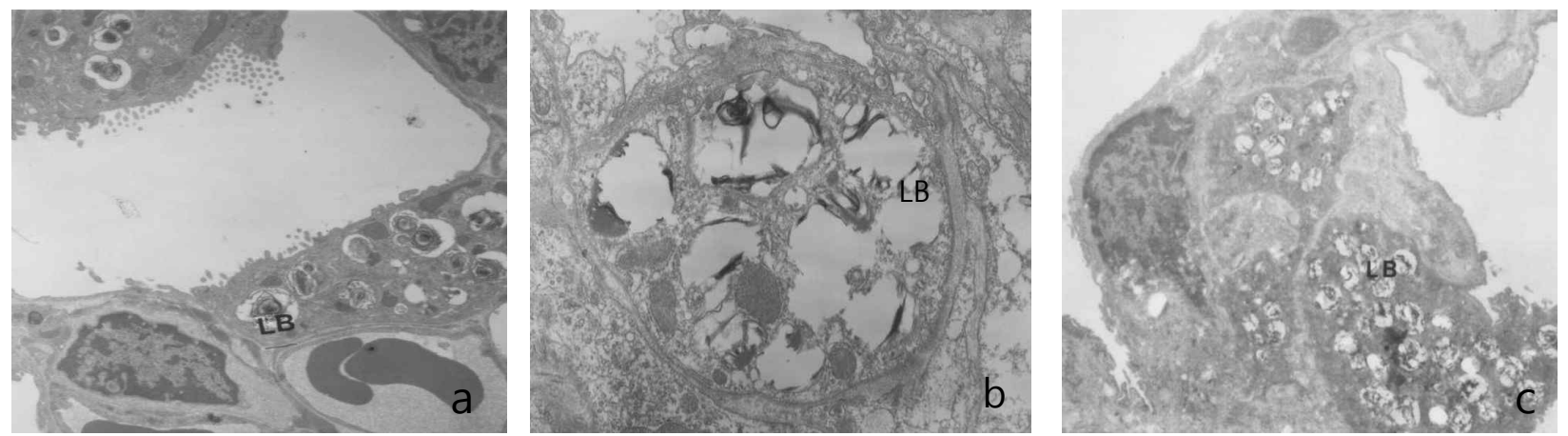

Fig. 2. The ultrastructural changes in the AT II cells after moxifloxacin treatment in the ETX-treated rats. In panel a, the AT II cell shows normal lamellar bodies in the cytoplasm (original mag $\times 4,000$ ). By contrast, in panel $b$ of the AT II cells in the ETX group, enlarged and vacuolated lamellar bodies are visible, reflecting that endogenous oxidative stress occurred in the lungs (original mag $\times 6,000$ ). Panel c shows the AT II cell of the moxifloxacin group. The lamellar bodies are not completely normal, but there is no vacuolization and hypertrophy of lamellar bodies, signifying the decreased endogenous oxidative stress (original mag $\times 4,000$ ).
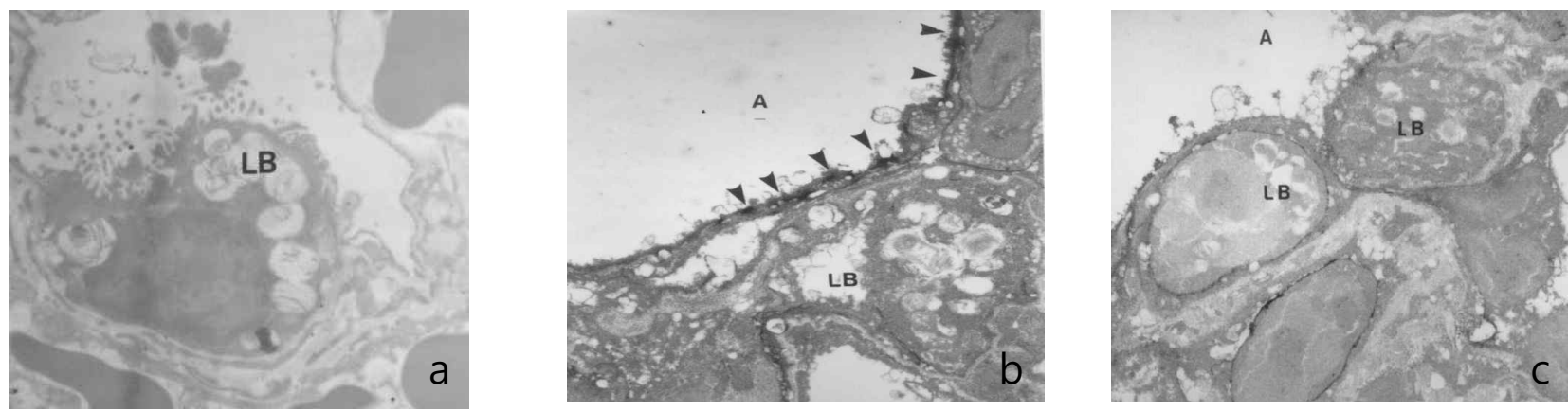

Fig. 3. Electron microscopic histochemistry for the detection of hydrogen peroxide in the lungs after moxifloxacin treatment. Panel a: In the sham group, cerrous perhydroxide, the reactive product of hydrogen peroxide and cerium chloride, is not visible in the AT II cell (original mag $\times 5,000$ ). Panel b: By contrast, dense deposits of cerrous perhydroxide granules are visible along the membrane of the AT II cell (arrow heads, original mag $\times 4,000$ ). Panel c: Moxifloxacin reduced the deposits of cerrous perhydroxide in the AT II cell (original mag $\times 4,000$ ). 

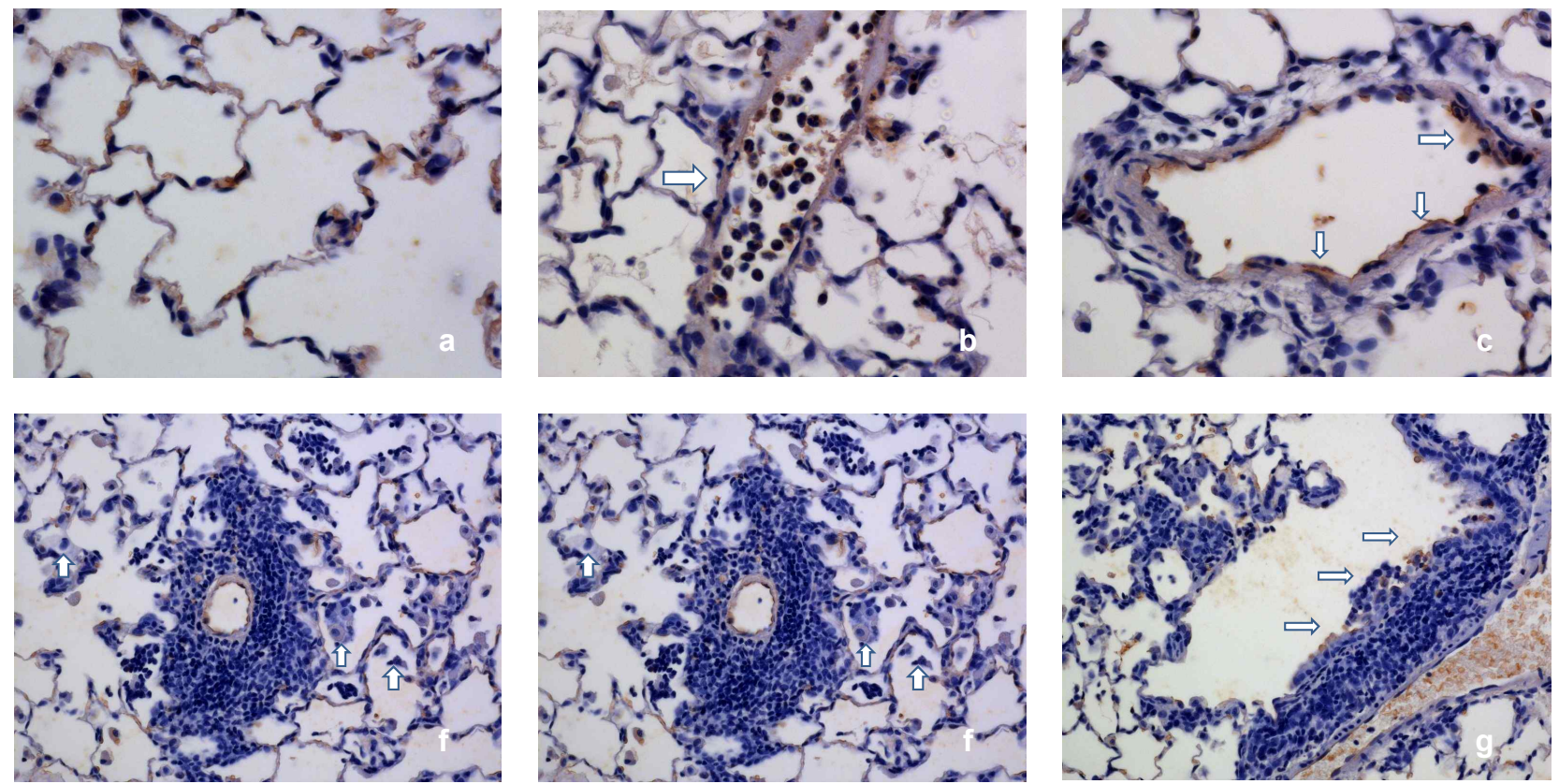

Fig. 4. Immunohistochemistry of cPLA2 in the lungs. Moxifloxacin suppressed the ETX-induced upregulated cPLA2 in the lung tissues. Fig 4a: In the sham group, the expression of cPLA2 (DAB-stained CPLA2) is not visible (DAB staining, original mag $\times 200$ ). Fig. $4 \mathrm{~b}$ : Note that the congested neutrophils reveal the stained cPLA2 in their cytoplasms, reflecting the activation of CPLA2 in the neutrophils by ETX (arrow, DAB staining, original mag $\times 200$ ). Fig 4c: Neutrophils migrated out of the vessel, and part of the endothelial barrier revealed activated CPLA2 (stained with DAB, arrows, original mag $\times 200$ ). Fig. $4 \mathrm{~d}$ : Moxifloxacin suppressed the migration of neutrophils into the alveoli, but in some alveoli, monocytes were visible (DAB staining, original mag $\times 100$ ). Fig $4 \mathrm{e}$, $\mathrm{f}$ : These phenomena were well observed at the perivascular area (arrows), and even if the perivascular accumulation of monocytes was prominent, few neutrophils were found, and the staining of cPLA2 was not visible $(\mathrm{DAB}$ staining, original mag $\times 200)$.
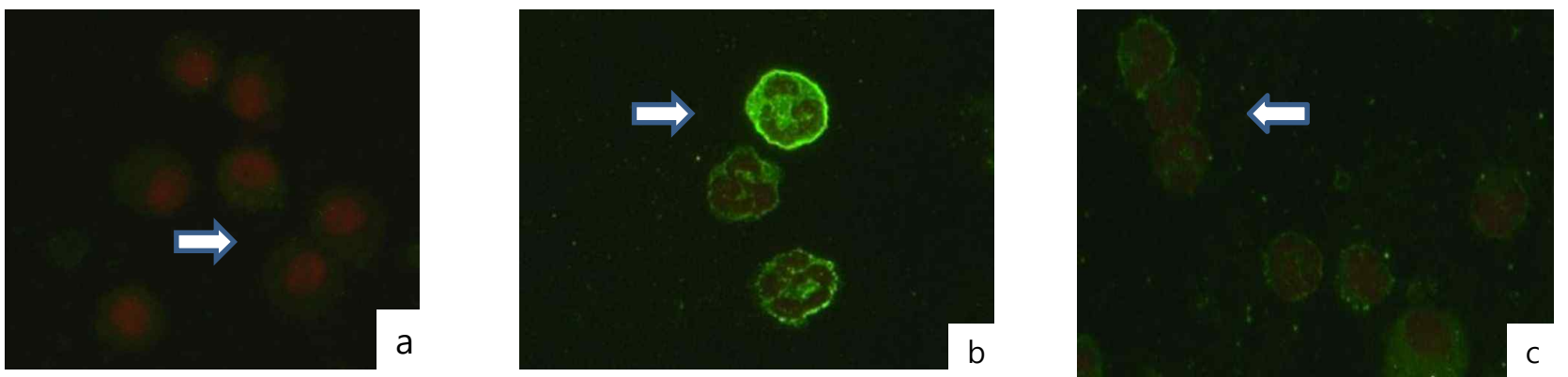

Fig. 5. Immunohistochemistry of cPLA2 in the BAL cells. Moxifloxacin inhibited the expression of cPLA2 in the BAL cells of the rats that had been given ETX intratracheally. Panel a: Almost all the BAL cells were monocytes devoid of cPLA2 expression (propidium iodide staining, original mag $\times 200$ ). Panel b: By contrast, enhanced expression of cPLA2 in the neutrophils was observed in the BAL cells of the ETX group (panel b, propidium iodide staining, original mag $\times 200$ ). Panel c: Moxifloxacin suppressed the expression of CPLA2 in the BAL cells of the rats that had been given ETX intratracheally (propidium iodide staining, original mag $\times 200$ ).

\section{Discussion}

The most common cause of ALI/ARDS is severe sepsis from a pulmonary source [23]. In spite of the intense investigation of the exact pathogenesis of ALI, the pathophysiological understanding of ALI-associated sepsis is still unsatisfactory. In ALI from sepsis, ETX plays an important role in starting epithelial and endothelial injury 


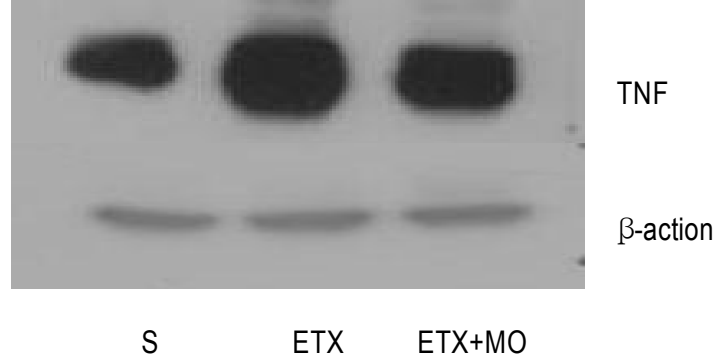

Fig. 6. Western blotting of TNFa in the lung tissues. Moxifloxacin suppressed the expression of TNFa in the lungs of the rats that had been given ETX intratracheally. Compared with the expression of TNFa in the lung tissues of the sham group, the expression of TNFa in the ETX group was upregulated. By contrast, moxifloxacin suppressed the elevated expression of TNFa in the lungs of the rats that had been given ETX. S: sham, ETX: endotoxin, MO moxifloxacin.

through the neutrophil-, cytokine-, and oxidant-mediated processes [4]. In all these inflammation processes, PLA2s are involved [19]. Although PLA2s have long been known as the regulators of the inflammatory process in ALI, the development of a therapeutic modality with the inhibition of PLA2 has been unsuccessful.

As has been known, ETX develops acute inflammatory lung injury. This was also demonstrated in the present study. Histologically, severe perivascular cuffing and disruption of the endothelial barrier were observed. Notably, the migration of phagocytes, especially neutrophils, was closely visualized in the present study. The floating and migration of neutrophils into the alveoli and the interstitial edema were evident after ETX insult. In the alveoli of the ETX group, neutrophils were clumped with the hyaline membranes, and atelectasis was found. These morphological changes in the lungs are the characteristic traits of ALI/ARDS [17]. Together with these morphological changes, the accumulation and migration of neutrophils were also proven by the lung MPO activity and BAL neutrophil count.

The present data demonstrated that ETX-induced lung injury is preceded by neutrophilic infiltration, which is a prerequisite for neutrophilic tissue injury. Although the mechanism is still obscure, moxifloxacin drastically ameliorated these inflammatory changes with the diminution of pulmonary edema and the migration of neutrophils into the alveoli. Instead of the migration of neutrophils into the alveoli, monocytes filled the alveoli, and in the examination of the BAL cells, monocytes and neutropils were found intermingled.

Even though the role of neutrophilic oxidative stress is partial and limited, in the initial stage of ETX-induced ALI, it has a pivotal role of causing endothelial and epithelial injury through the disruption of the pulmonary surfactant [11]. The activation of PLA2s by ETX or by the cytokines secreted from phagocytes leads to the hydrolysis of the phospholipids of the surfactant, through which process toxic mediators are produced [6,7]. The resultant phenomenon is the peculiar changes in the AT II cells, such as hypersecretion of the pulmonary surfactant and enlargement and vacuolization of the lamellar bodies in the cytoplasms of the AT II cells in the lungs [9]. According to Martensson [15], these peculiar changes in the AT II cells are derived from oxidative stress, especially endogenous oxidative stress by the free radicals from neutrophils. In the present study, the AT II cells were characterized by the traits of endogenous oxidative stress, such as enlargement and vacuolization of the lamellar bodies and surfactant denaturation.

Under the effects of ETX, moxifloxacin suppressed or ameliorated the oxidative-stress-induced AT II cell morphology. The decreased production of hydrogen peroxide by moxifloxacin reflected the diminished endogenous oxidative stress. The amount of cerrous perhydroxide was reduced by moxifloxacin in the ETX group. These morphological and histochemical evidences show the effectiveness of moxifloxacin in alleviating acute inflammatory injury caused by ETX.

As mentioned earlier, ETX-induced ALI was closely linked to the activation of a PLA2 and cytokine network; therefore, the decreased activity of PLA2s might have been one of the causes of the diminished inflammatory changes in the lungs in this study. Of the many types of PLA2s, cPLA2s have been recognized as initiating the inflammatory process of ALI [20]. The roles of cPLA2s in ALI are diverse. The end products of activated cPLA2s provoke free-radical release from the neutrophils by activating NADPH oxidase to change the hemodynamics and to upregulate the adhesion molecules for the phagocytes, and have direct cytotoxic effects on the endothelial and epithelial cells [14].

In the present study, phagocytes were not found in the alveoli of the sham group, but in the ETX group, activated-cPLA2-containing neutrophils were congested in the capillaries. The activated-cPLA2-containing neutrophils 
migrated through the disrupted endothelial barrier into the alveoli. Even the endothelial cells showed increased expression of cPLA2. Moxifloxacin almost completely abolished these neutrophils, whose cytoplasms contained activated cPLA2s in the alveoli. Through the effect of moxifloxacin, the alveoli were rid of neutrophils, and very small portions of the alveoli were filled with monocytes, in which the expression of cPLA2s was not found. These morphological findings are consistent with the report of Uriarte and associates [25] in which they insisted that moxifloxacin inhibited the migration of neutrophils into the endothelial cells by inhibiting the production of TNF. By inhibiting the production of cytokines such as IL-6, IL-8, and TNF from monocytes, moxifloxacin has been alleged to exhibit the anti-inflammatory effects of moxifloxacin [22].

Another interesting result of the present study is that in the BAL cells, moxifloxacin also dramatically suppressed the cPLA2s in the phagocytes, especially in the neutrophils. In the sham group, almost all the BAL cells were monocytes, which were deficient in the expression of cPLA2s. On the other hand, almost all the BAL cells from the ETX group were neutrophils, which conspicuously expressed cPLA2 in their cytoplasm. On the other hand, moxifloxacin almost completely suppressed the expression of cPLA2s in the monocytes and neutrophils in the BAL cells. It is not possible to deduce from these experiment results if the inhibitory effect of moxifloxacin on the activation of cPLA2s was direct. Based on the decreased expression of TNFa by moxifloxacin, however, it could be inferred that the CPLA2-inhibiting effect of moxifloxacin is indirect, through the suppression of inflammatory cytokines.

Taken together, these results suggest that moxifloxacin has an anti-inflammatory effect of ameliorating acute inflammatory injury through the suppression of CPLA2s in the lungs of rats.

\section{Acknowledgements}

This work was supported by a grant from Research Institute of Medical Science, Catholic University of Daegu (2011-Grant No. 2011-11). Special gratitude goes to GRH for the completion of this study.

\section{References}

1. Bhatia, M. and S. Moochhala. 2004. Role of inflammatory mediators in the pathophysiology of acute respiratory distress syndrome. J. Pathol. 202, 145-156.

2. Brown, R. E., J. L. Jarvis, and K. J. Hyland. 1989. Protein measurement using bicinchoninic acid: elimination of interfering substance. Anal. Biochem 180, 136-139.

3. Dallhof, A. and I. Shalit. 2003. Immunoregulatory effects of quinolones. Lancet Infec. Dis. 3, 359-371.

4. Delclaux, C., S. Rezaiguia-Delclaux, C. Delacourt, C. Brun-Buisson, C. Lafuma, and A. Harf. 1997. Alveolar neutrophils in endotoxin-induced acute lung injury in rats. $A m$ J. Physiol. 273, L104-112.

5. Goldblum, S. E., K. E. Wu, and M. Jay. 1985. Lung myeloperoxidase as a measurement of leukostasis in rabbits. J. Appl. Physiol. 119, 101-110.

6. Hite, R. D., M. C. Seeds, R. B. Jacinto, R. Balasubramania, and M. Waite. 1998. Hydrolysis of surfactant associated phosphatidylcholine by mammalian secretory phospholipase A2. Am J. Physiol. 275, L740-747.

7. Holm, B. A., L. Keicher, M. A. Liu, J. Sokolowski, and G. Enhorning. 1991. Inhibition of pulmonary surfactant function by phospholipases. J. Appl. Physiol. 71, 317-321.

8. Huang, H., C. Shieh, K. W. Yu, K. Cheng, and C. Chen. 2008. Comparing the protective effects of ciprofloxacin, moxifloxacin and levofloxacin in mice with lipopolysaccharide-induced acute lung injuries. Repirology 13, 47-52.

9. Hybertson, B. M., Y. M. Lee, H. G. Cho, O. J. Cho, and J. E. Repine. 2000. Alveolar type II cell abnormalities and peroxide formation in lungs of rats given IL-1 intratracheally. Inflammation 24, 289-303.

10. Kitsioluli, E., G. Nakos, and M. E. Lekka. 2009. Phospholipase A2 subclasses in acute respiratory distress syndrome. Biochim Biophys. Acta 1792, 941-53.

11. Lekka, M. E., S. Liokatis, C. Nathanail, V. Galani, and G. Nakos. 2004. The impact of intravenous fat emulsion administration in the acute lung injury. Am J. Respire. Crit. Care Med 169, 638-644.

12. Leslie, C. C. 1997. Properties and regulation of cytosolic phospholipase A2. J. Biol. Chem 272, 709-712.

13. Levy, R., R. Dana, I. Hazan, G. Weber, and R. Smoliakov. 2009. Elevated cytosolic phospholipase A2 expression and activity in human neutrophils during sepsis. Blood 95, 660-665.

14. Levy, R. 2006. The role of phospholipase A2-alfa in regulation of phagocytic functions. Biochim Biophys. Acta 1761, 1323-1334.

15. Martensson, J., A. Jain, W. Frayer, and A. Meister. 1989. Glutathione metabolism in the lung: inhibition of its synthesis leads to lamellar body and mitochondrial defects. Proc. Natl. Acad Sci. 86, 5296-5300.

16. Matthay, M. A. and R. L. Zemans. 2011. The acute respiratory distress syndrome: Pathogenesis and Treatment. Ann. Rev. Pathol. 6, 147-163.

17. Mendez, J. L. and R. D. Hubmayr. 2005. New insight into the pathology of acute respiratory failure. Curr. Opin. Crit. Care 11, 29-36 
18. Mueller, J. M., H. W. Loems Ziegler-Heitbrock, and P. A. Baeuerle. 1993. Nuclear factor kappa B, a mediator of lipopolysaccharide effects. Immunobiol. 187, 233-256.

19. Nagase, T., N. Uozumi, T. Aoki-Nagase, K. Terawaki, and S. Ishii. 2003. A potent inhibitor of cytosolic phospholipase A2, arachidonyl trifluoroethyl ketone, attenuates LPS-induced lung injury in mice. Am J. Lung Cell Mol. Physiol. 234, L720-726.

20. Nagase, T., N. Uozumi, S. Ishii, K. Kume, and T. Izumi. 2000. Acute lung injury by sepsis and acid aspiration: a key role for cytosolic phospholipase A2. Nature Immunol. 1, $42-46$.

21. Pittet, J. F., R. C. Mackersie, T. R. Martin, and M. A. Matthay. 1997. Biological markers of acute lung injury: prognostic and pathogenetic significance. Am J. Respir. Crit. Care Med 155, 1187-1205.

22. Shalit, I., D. Halperin, D. Haite, A. Levitov, and J. Romano. 2006. Anti-inflammatory effects of moxofloxacin on IL-8, IL-1 $\beta$ and TNF $\alpha$ secretion and NFkB and MAP-kinase activation in human monocytes stimulated with Aspergillus fumigatus. J. Antimicr. Chemother. 57, 230-235.
23. Sorbo, D. and A. S. Slutsky. 2011. Acute respiratory distress syndrome and multiple organ failure. Curr. Opin. Crit. Care 17, 1-6.

24. Suter, P. M., E. Suter, P, Girardin, P, Roux-Lombard, E. Grau, and J. Dayer. 1992. High bronchoalveolar level of tumor necrosis factor and its inhibitors, interleukin-1, interferon, and elastase, in patients with adult respiratory distress syndrome after traumatic shock or sepsis. Am Rev. Respir. Dis. 145, 1016-1022.

25. Uriarte, S. M., R. E. Molestina, R. D. Miller, J. Bernabo, and A. Farinati. 2004. Effects of fluoroquinolones on migration of human phagocytes through Chlamydia pneumoniae-infected and tumor necrosis factor alpha-stimulated endothelial cells. Antimicr. Agent Chemother. 48, 2538-2543.

26. Warren, J. S., R. G. Kunkel, R. H. Simon, K. J. Johnson, and P. A. Ward. 1989. Ultrastructural cytochemical analysis of oxygen radical mediated immunoglobulinA immune complex induced lung injury in rat. Lab. Invest. 60, 651-658.

27. Warren, L. L. and G. P. Downey. 2001. Neutrophil activation and acute lung injury. Curr. Opin. Crit. Care 7, 1-7.

초록 : 흰쥐에서 내독소로 유도된 급성 폐손상에서 moxofloxacin의 개선효과

이영만 ${ }^{1} *$ 최휘건 ${ }^{2}$

(대구가톨릭대학교 의과대학 ${ }^{1}$ 생리학교실, ${ }^{2}$ 생화학교실)

흰쥐에서 내독소로 유도된 급성 폐손상에서 moxifloxacin의 효과를 형태학적으로 호중구의 폐장 내 침윤 및 세포질형 포스포리파아제(cytosolic phospholipase A2) 발현과 관련하여 알아보았다. 내독소는 잘 알려진대로 흰 쥐에서 급성 폐손상을 유발하였고 이때 폐장 내의 호중구의 침윤 및 폐장 및 호중구에서의 세포질형 포스포리파 아제의 발현이 증가하였고, 또한 염증성 사이토카인의 일종인 종양괴사성인자(tumor necrosis factor)의 발현도 증가하였다. 전자현미경을 이용한 산소기 생성의 검사에서도 내독소에 의하여 산소기의 생성이 폐장 내에 증가 한 사실을 확인하였고, 산화성 스트레스에 유발되는 제 2 형 폐포세포에서의 층상체의 변화도 관찰하였다. 면역변 환효과가 있다고 알려진 moxifloxacin은 이러한 변화들을 억제하고 형태학적으로 내독소에 의한 급성 폐손상을 현저히 감소시켰다. 